\title{
Multi Respon Ranking Pada Percakapan Layanan Travel Berdasarkan Riwayat Obrolan
}

\author{
Uli Rizki \\ Program Pasca Sarjana Universitas Amikom Yogyakarta \\ Jl. Ring Road Utara, Condong Catur, Sleman, Yogyakarta, (0274) 884201 - 207 \\ uli.rizki@students.amikom.ac.id
}

\begin{abstract}
Abstrak
Membangun sebuah chatbot tidak lepas dari basis pengetahuan. Basis pengetahuan bisa diperoleh dari data yang telah diberi label oleh pengembang, dokumen yang telah di konversi menjadi pre-processing data, atau informasi yang diambil dari media sosial. Dalam hal ini, data yang digunakan sebagai pengetahuan adalah riwayat obrolan. Dialam riwayat obrolan tersebut tentu banyak sekali variasi jawaban dan menungkinkan satu pertanyaan menimbulkan banyak jawaban.

Untuk mengatasi multi respon tersebut maka dibuatlah pemeringaktan respon. Adanya pemeringkatan, tentu respon yang diinginkan oleh pengguna akan lebih sesuai. Tantangan dalam pemeringkatan adalah bagaimana mendapatkan inti dari sebuah pertanyaan dan menemukan pasangan tanya jawab dari data. Hal tersebut bisa diselesaikan dengan model sequence to sequence. Namun, permasalahan yang akan muncul adalah konsistensi jawaban. Adanya banyak riwayat obrolan dari layanan travel tentu menimbulkan banyak jawaban mesi inti dari pertanyaan adalah sama. Untuk itu Algoritma CNN sebagai solusi untuk permasalahan tersebut. Penelitian ini menggunakan convolutional sequence to sequence yang akan diterapkan untuk respon ranking. Kami memandingkan efisiensi dari model ini. Dengan melakukan perbandingan, model ini menunjukan hasil akurasi sebesar $86.7 \%$.
\end{abstract}

Kata kunci:Chatbot, Sequence to sequence, $\mathrm{CNN}$

\section{PENDAHULUAN}

Chatbot merupakan salah satu program dari kecerdasan buatan dalam simulasi percakapan interaktif kepada pengguna (manusia) melalui text, suara atau visual. Dalam mengenali dan memberikan respon yang alami layaknya percakapan manusia, chabot menggunakan pendekatan Natural Language Processing (NLP). Tantangan dalam penerapan NLP diantaranya yaitu ambigutias bahasa alami, representasi pengetahuan, tingkatan informasi, dan beragam aplikasi untuk teknologi bahasa.

Akurasi dalam menyajikan jawaban dalam sebuah percakapan robot terus dilakukan. Berbagai pendekatan dan model meningkatkan efisiensi dalam mengenali pola percakapan dan memberikan jawaban dengan cepat dari dasar pengetahuan pada sebuah percakapan manusia dan mesin. Salah satu pendekatan yang sering dilakukan adalah menyandikan pasangan teks dengan menggunakan fitur leksikal, sintaksis dan semantik yang kemudian menghitung ukuran kesamaan antara representasi pada sebuah kalimat.
Untuk memberikan respon layaknya percakapan manusia, chatbot mengandalkan basis pengetahuan yang sudah tersusun atau masukan dari pengembangnya. Hal tersebut memberikan masalah jika membutuhkan banyak sekali pengetahuan. Kemudian, untuk meningkatkan akurasi biasanya menggunakan metode pelabelan pada setiap pola kalimat. Ini akan menjadi pekerjaan yang melelahkan jika harus memberikan label pada gudang data dan tidak efektif jika diterapkan untuk skala industri. (Bowen $\mathrm{Wu}, \mathrm{dkk}$ )[1]

Pendekatan lain yang digunakan adalah menggunakan framework sequence to sequence atau urutan konteks percakapan (Jiwei Li, dkk, 2017)[2]. Metode ini di implementasikan ketika menggunakan data yang berasal dari percakapan group atau riwayat obrolan tertentu. Dalam percakapan sebuah group obrolan tentunya akan banyak jawaban yang berbeda tergantung dari personal penjawab. Adanya urutan (sequence) tentunya akan menemukan jawaban dari pertanyaan yang sama. Tetapi metode urutan ini memiliki kelemahan pada konsitensi respon. Respon yang diberikan tergantung 
dari urutan yang pada suatu waktu diperbaharui sehingga dengan pertanyaan yang sama dengan waktu berbeda akan memberikan respon berbeda pula.

Permasalahan konsistensi dapat disolusikan dengan pemeringkatan respon dengan menggunakan algoritma CNN (Akshay Chaturvedi, dkk, 2018)[3]. Kemudian untuk meningkatkan relevansi sesuai dengan permintaan pengguna, ditambahkan fitur lain yaitu dengan pendekatan konten (Bingquan Liu, dkk, 2018)[4]. Pendekatan konten tersebut mengambil profil pengguna, baik dari input ke sistem maupun mengambil dari akun media sosial terkait profil pribadi pengguna. Profil pengguna yang dihubungkan dengan konten yang di posting, tanggapan, dan informasi pribadi digunakan sebagai bahan pertimbangan perspektif pengguna sehingga respon akan dipilihkan lebih tepat untuk orang tertentu.

Banyaknya penelitian terdahulu serta banyaknya referensi mengenai pemeringkatan respon chatbot dengan menggunakan algoritma CNN dengan beberapa model pendekatan. Namun, dari penelitian-penelitian sebelumnya mayoritas menggunakan dataset dari percakapan lebih luas dan dengan bahasan yang belum spesifik. Oleh karena itu, penelitian ini akan menggunakan data pengetahuan riwayat obrolan dalam pemeringkatan respon sistem percakapan dengan menggunakan model pendekatan sequence to sequence dan mengunakan algoritma $\mathrm{CNN}$.

\section{METODE PENELITIAN}

a. Jenis, Sifat, dan Pendekatan Penelitian

1) Jenis Penelitian

Chatbot bukanlah sebuah hal baru dalam machine learning seperti saat sekarang ini, bahkan sudah banyak diimplementasikan di banyak industri layanan online. Banyak sekali penelitian untuk melatih percakapan sistem layaknya percakapan alami manusia. Penelitian dengan berbagai model dan pendekatan mampu untuk mengambil informasi tidak hanya dari basis pengetahuan yang disediakan didalam sistem chatbot sendiri tetapi sudah mengambil informasi dari luar bahkan mengambil profil pribadi berdasarkan akun media sosial dibenamkan dalam sistem chatbot itu sendiri.
Dalam hal ini, penelitian ini dilakukan dengan melakukan ekperimen dengan cara menerapkan model untuk respon ranking chatbot dengan menggunakan riwayat obrolan sebagai basis pengetahuan chatbot tersebut.

\section{2) Sifat Penelitian}

Penelitian ini bersifat kausal yaitu model yang akan diterapkan memberikan hasil bagaimana pendekatan ini bekerja. Dan memperoleh informasi seberapa besar akurasi yang bisa ditunjukan dengan menggunakan model yang diterapkan.

\section{3) Pendekatan Penelitian}

Dalam pembelajaran sistem terdapat banyak metode yang bisa digunakan tergantung dari permasalah yang akan diselesaikan. Dimulai dari Natural Language Processing dan Deep Learning. Dua konsep besar tersebut bisa ditarik lagi metode yang ditunjukan pada gambar dibawah ini.

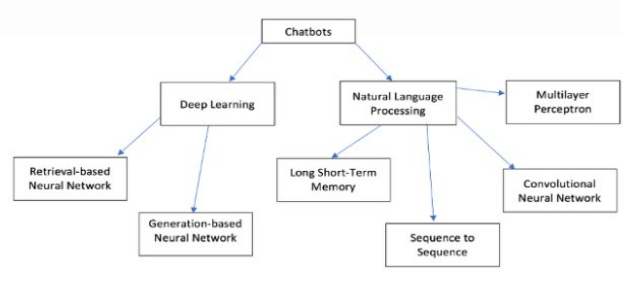

Gambar 1. Ilustrasi Peta Konsep Chatbot

Ada terdapat banyak metode dalam membaca informasi dalam sebuah chatbot seperti terlihat pada gambar 3, namun pada penelitian ini akan dikhususkan pada penggunaan metode Sequence to Sequence dan Convolutional Neural Network. Metode seq2seq akan memproses urutan sebuah kalimat dan algoritma CNN digunakan sebagai hidden layer yang akan menghitung atau me-ranking kalimat sebagai kandidat respon yang paling berhubungan.

Secara garis besar langkah-langkah yang dilakukan untuk melakukan respon ranking pada sebuah sistem percakapan adalah dengan memecah sebuah kalimat berdasarkan urutan-urutan kata. Yang selanjutnya akan di filter menggunakan algoritma CNN dengan beberapa layer 
tersembunyi untuk melihat atau mencari kata yang paling relevan dengan basis pengetahuan, dalam hal ini riwayat obrolan.

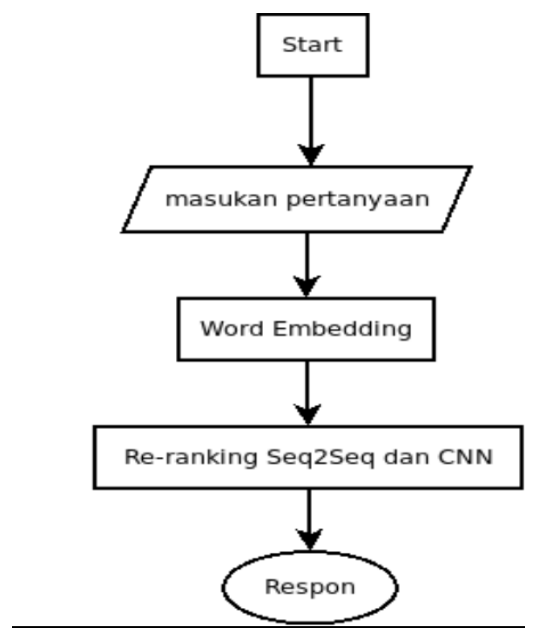

Gambar 2. Proses Respon ranking

Seperti yang terlihat dalam gambar 4, model re-rangking menggunakan seq2seq dan CNN akan mengadopsi dari penelitian Abstract Text Summarization with a Convolutional Seq2seq Model, Zhang dkk, MDPI 2019. Pertama sebuah kalimat dari user masuk ke input layer, disini akan dilakukan proses pemecahan kalimat. Selanjutnya, akan masuk ke Hidden State Wordaye untuk dilakukan perangkingan yang didukung dengan Hidden State Sentence Layer untuk proses filtering.

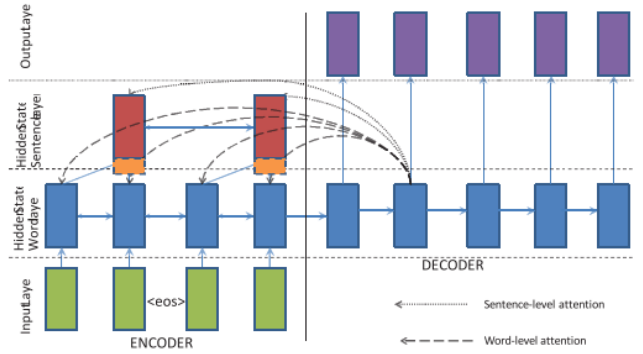

Gambar 5. Mekanisme Respon Ranking

\section{b. Metode Pengumpulan Data}

Dalam pelaksanaan penelitian mengenai respon ranking ini tentunya dibutuhkan berbagai komponen pendukung demi kelancaran penelitian. Salah satu komponen pendukung yang tidak bisa dipisahkan adalah data sebagai bahan ujicoba.
Sebagai salah satu bahan ujicoba dalam penelitian ini digunakan dataset riwayat obrolan dari layanan jasa penjualan tiket online di salah satu perusahaan startup di Yogyakarta.

Terdapat lebih dari 10000 percakapan untuk layanan penjualan tiket pesawat. Dalam riwayat obrolan tersebut merupakan obrolan dari 10 customer service dalam pelayanan dari tahun 2018 .

\section{c. Metode Analisis Data \\ 1) Data Training}

Misalkan dataset dengan komponen data $\mathrm{N}$, komponen $\left(x^{(i)}, t^{(i)}\right.$ ) terdiri dari teks sumber direpresentasikan sebagai $\boldsymbol{x}^{(i)}$ dan kata kunci target Mi atau kalimat kunci yang dilambangkan $t^{(i)}=\left(t^{(i), 1}, t^{(i), 2}, \ldots, t^{(i) M_{i}}\right.$, sebagai

\section{2) Urutan Kalimat}

Untuk urutan input $\mathrm{x}=\left(x_{1}, \ldots, \mathrm{x}_{m}{ }^{\prime}\right.$, pertama-tama kita menyatakannya sebagai vektor dimensi rendah $\mathbf{u}=\left(u_{1}, \ldots, \mathrm{u}_{m}\right.$,', di mana $\boldsymbol{u}_{j} \in \boldsymbol{R}^{d}$. Sedangkan untuk embeddings posisi, pertama-tama kita memperoleh vektor untuk merekam posisi absolut suatu elemen dalam suatu urutan. Kemudian kami menggunakan lapisan embedding untuk mengubah representasi jarang dan diskrit ini menjadi embeddings kontinu sebagai $\mathrm{p}=\left(p_{1}, \ldots, \mathrm{p}_{m}^{\prime}\right)_{\text {di mana }} p_{j}$ $\in \boldsymbol{R}^{d}$, sehingga memungkinkan untuk mengetahui bagian urutan mana yang sedang diproses. $d$ adalah dimensi dari posisi embeddings dan embeddings elemen urutan input. Kami menggunakan kombinasi kedua embeddings untuk membentuk embeddings elemen input $\mathrm{e}=\left(u_{1}+\mathrm{p}_{1}, \ldots, \mathrm{u}_{m}+\mathrm{p}_{m_{1}}\right.$. Demikian pula kami juga menambahkan posisi embeddings ke embeddings elemen keluaran decoder, dan kemudian mengembalikan ke decoder.

\section{3) Convolutional Seq2Seq Model}

Kami membagi arsitektur lapisan convolutional pada encoder dan decoder yang akan menghitung status perantara melalui elemen input. Kami merepresentasikan output dari layer ke-l sebagai $z^{1}=\left(z_{1}^{\prime}, \ldots, z_{m}^{\prime}\right.$, untuk encoder dan $h^{1}=\left(h_{1}^{\prime}, \ldots, \mathrm{h}_{m}^{\prime}\right.$, untuk decoder. 
Setiap lapisan terdiri dari konvolusi satu dimensi dan non-linearitas. Jika decoder memiliki satu layer dengan lebar kernel menjadi k, maka outputnya h1 akan saya kompres informasi elemen input $\mathrm{k}$. Untuk memperbesar panjang elemen input, kami menumpuk blok satu sama lain, misalnya, menumpuk 6 blok dengan $\mathrm{k}=5$ dapat mewakili 25 elemen input. Jika diperlukan, non-linearitas memungkinkan model kami untuk menangani seluruh urutan input atau hanya beberapa elemen. Keunggulan komputasi model kami adalah melakukan komputasi paralel yang jauh lebih efisien daripada model RNN tradisional yang dikomputasi satu elemen dengan satu elemen. Seperti disebutkan dalam Bagian 1, untuk mewakili urutan dengan kata-kata, $\mathrm{CNN}$ hanya membutuhkan operasi $O_{(n / k)}$, sedangkan RNN membutuhkan operasi $O_{(n \text { : }}$ Namun, model CNN hierarkis ini tidak seefisien model CNN tradisional karena model kami harus menumpuk lapisan $\mathrm{CNN}$ untuk mewakili urutan yang lebih ekspresif, sementara model CNN tradisional hanya membutuhkan satu lapisan untuk menjelajahi seluruh urutan.

\section{d. Alur Penelitian}

Tahap-tahap penelitian respon ranking chatbot adalah sebagai berikut :

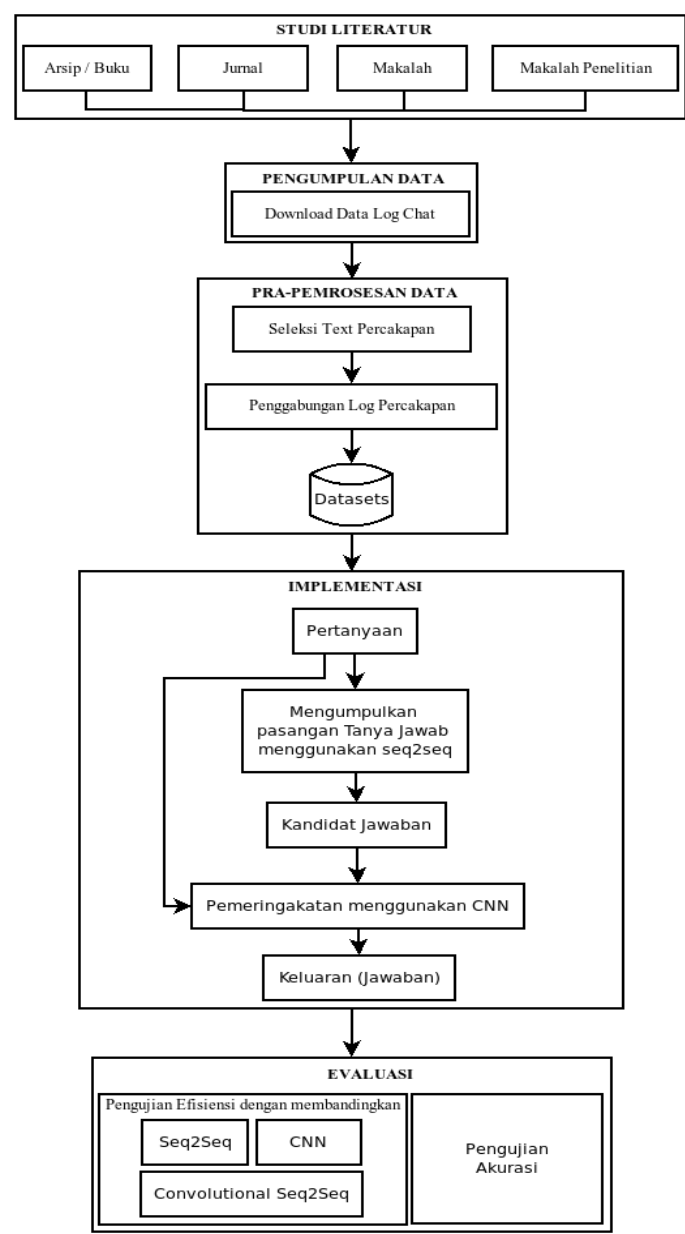

Gambar 3. Alur Penelitian

\section{TINJAUAN PUSTAKA}

Severyn, $d k k$ melakukan penelitian mengenai arsitektur CNN untuk merangkai pasangan teks pendek dan fungsi kesamaan untuk dikatikan dengan kata-kata yang menjadi dasar pengetahuan berdsarkan data training yang tersedia. Kelebihan metode yang digunakan mampu mengalahkan sistem stateof-art sebelumnya yaitu 3\% poin absolut di Mean Average Precision (MAP) dan Mean Reciprocal Rank (MRR). Penelitian ini juga menjawab tantangan dari forum tanya jawab TREC.

$W u, d k k$ juga melakukan penelitian dengan menggunakan pendekatan Sequential Matching Network (SVM). Penelitian ini mencocokan respon dengan setiap konteks dalam sebuah ucapan dari pengguna, dan menyaring pencocokan penting sebagai vektor dengan operasi pengumpulan. Vektor tersebut diakumulasikan dalam sebuah urutan melalui Recurrent Neural Network (RNN) yang memodelkan hubungan antar ucapan. 
Bowen, dkk melakukan penelitian menggabungkan lapisan konvolusional dengan memahami petunjuk semantik dalam percakapan, berdasarkan representatif efektif untuk setiap kalimat. Dalam hal ini, peneliti juga menambahkan lapisan berbasis GRU untuk membangun model peringkat kandidat sehingga mengambil permodelan kalimat menggunakan $\mathrm{CNN}$ dan RNN sebagai permodelan urutan. Dengan permodelan tersebut mendapatkan akurasi sebesar 78,6\%.

Penelitian terkait juga diimplementasikan pada tanya jawab dalam sebuah e-commerce. Dalam sebuah percakapan tanya jawab permasalahan yang timbul adalah mencocokan sumber pengetahuan dengan pemrosesan bahasa alami. Untuk itu peneliti mengusulkan kerangka kerja baru yang dapat secara efektif dan efisien menyesuaikan pengetahuan yang dibagikan dari domain yang kaya sumber pengetahuan ke sumber yang kurang pengetahuan. Hasilnya, performa dari pelayanan e-commerce meningkat dengan $\mathrm{F} 1=0.681$ dengan waktu 80.7 per query . (Jianfei Yu, dkk, 2018)

\section{HASIL DAN PEMBAHASAN}

\section{a. Membuat Datasets}

Pertama, data kami ambil dari log chat dari email yang berekestensi .eml, terlihat seperti gambar di bawah ini.

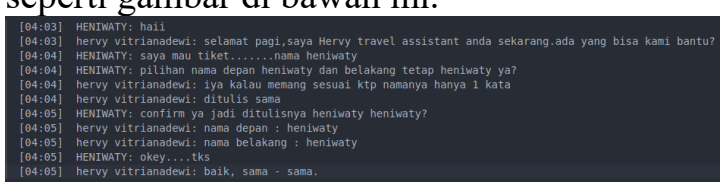

Gambar 4. Log Chat dari email

Untuk melakukan penggabungan teks percakapan, penulis menggunakan skrip kode dengan bahasa python. Setelah dilakukan penggabungan maka data terlihat seperti dibawah ini.

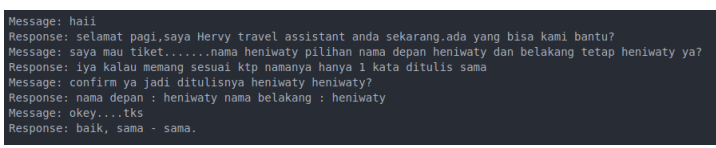

Gambar 5. Chat yang sudah digabungkan

\section{b. Word Vector}

Untuk menghasilkan vektor kata, kami menggunakan pendekatan klasik model Word2Vec. Ide dasarnya adalah bahwa model menciptakan vektor kata dengan melihat konteks dengan kata-kata yang muncul dalam kalimat. Kata-kata dengan konteks yang sama akan ditempatkan berdekatan dalam ruang vektor.

\section{c. Sequence to Sequence Model}

Setelah melakukan pra-pemrosesan data maka masuk ke dalam implementasi yaitu dengan mengidentifikasi pertanyaan yang diajukan oleh pengguna chatbot.

Misalnya user mengajukan pertanyaan seperti "Apakah harga sudah termasuk bagasi ?"

Dalam proses ini pertanyaan tersebut akan

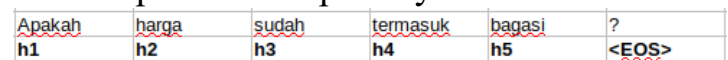
dikonversi sebagai berikut:

\section{Gambar 6. Identifiaski pertanyaan}

Kemudian dengan perhitugan dengan menggunakan rumus yang telah dijelaskan pada 2.3.2 maka pertanyaan tersebut yang akan dijadikan sebagai encoder. Dan kemudian mesin akan menemukan pasangan pertanyaan dan jawaban. Jawaban tersebut adalah bentuk dari decoder. Seperti gambar

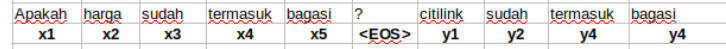
dibawah ini.

Gambar 7. Bentuk encoder dan decoder seq2seq

\section{d. Convolutional Neural Network}

Setelah dilakukan pengecekan pasangan pertanyaan dan jawaban, maka kandidat respon akan diranking. Namun, dalam proses pemeringkatan, pertanyaan akan difilter lagi menggunakan algoritma CNN.

\section{1) One-hot vector}

Dalam tahap ini, kalimat atau pertanyaan akan diubah menjadi angka 1 atau 0 berdasarkan jumlah kata dalam pertanyaan yang nantinya akan menjadi sebuah matrix yang akan melalui beberapa proses perhitungan. Perubahan one-hot vector, dapat ditunjukan tabel 1.

Tabel 1. One-hot Vector 


\begin{tabular}{|l|c|c|c|c|c|c|}
\hline & \multicolumn{7}{|c|}{ One-hot vector } \\
\hline & Apakah & harga & sudah & termasuk & bagasi & $?$ \\
\hline apakah & 1 & 0 & 0 & 0 & 0 & 0 \\
\hline harga & 0 & 1 & 0 & 0 & 0 & 0 \\
\hline sudah & 0 & 0 & 1 & 0 & 0 & 0 \\
\hline termasuk & 0 & 0 & 0 & 1 & 0 & 0 \\
\hline bagasi & 0 & 0 & 0 & 0 & 1 & 0 \\
\hline$?$ & 0 & 0 & 0 & 0 & 0 & 1 \\
\hline
\end{tabular}

\section{2) Convoluted Feature}

Kemudian setiap vektor akan dikalikan dengan kernel yang mana akan memasangkan kata-kata dalam pertanyaan. Kami menggunakan contoh kernel $3 \times 3$ untuk menghitung pasangan kata yang akan diubah sebagai matrix.

Tabel 2. Kernel $3 \times 3$
\begin{tabular}{|l|l|l|}
\hline \multicolumn{3}{|c|}{ Kernel $3 \times 3$} \\
\hline & & \\
\hline 1 & 0 & 1 \\
\hline 0 & 1 & 0 \\
\hline 1 & 0 & 1 \\
\hline
\end{tabular}

\section{Tabel 3. Convoluted Feature}

\begin{tabular}{|c|c|c|c|}
\hline \multicolumn{4}{|c|}{ Convoluted Feature } \\
\hline 3 & 0 & 1 & 0 \\
\hline 0 & 3 & 0 & 1 \\
\hline 1 & 0 & 2 & 0 \\
\hline 0 & 1 & 0 & 3 \\
\hline
\end{tabular}

Kemudian hasil perkalian dengan kernel ditunjukan tabel 3 .

\section{3) Max Polling}

Convoluted Feature akan di filter lagi dengan lapisan $2 \times 2$ untuk mendapatkan nilai maksimal dalam setiap lapisan. Dari tabel 3 akan diambil nilai maksimal dari 4 kolom mendapat max-polling seperti tabel 4.

Tabel 4. Max Polling

\begin{tabular}{|c|c|}
\hline \multicolumn{2}{|c|}{ Max Polling } \\
\hline 3 & 1 \\
\hline 3 & 2 \\
\hline 1 & 3 \\
\hline
\end{tabular}

\section{e. Eksperimen}

Dengan menggunakan dataset dari riwayat percakapan model yang diusulkan dapat meningkatkan akurasi. Jika hanya menggunakan seq2seq lebih sedikit akurasi karena banyaknya kandidat jawaban yang berbeda. Dengan tambahan $\mathrm{CNN}$ dapat meningkatkan akurasi dalam pemeringkatan respon sebuah chatbot.
Tabel 5. Hasil TestModel

\begin{tabular}{cc}
\hline Model & Akurasi \\
\hline Seq2seq & $68.20 \%$ \\
CNN & $84.10 \%$ \\
Conv-seq2seq & $86.7 \%$ \\
\hline
\end{tabular}

\section{KESIMPULAN DAN SARAN}

a. Kesimpulan

Dengan menggabungkan dua model yaitu seq2seq dan CNN ternyata dapat meningkatkan akurasi sebesar $86.7 \%$. Dengan menggunakan riwayat obrolan. Jika hanya menggunakan seq2seq sangat memungkinkan jawaban yang berulang sesuai dengan penelitian sebelumya.

\section{b. Saran}

Untuk kedepannya, bisa menambah dataset atau mengurangi dataset untuk menemukan kondisi terbaik ketika menggunakan model convolusional seq2seq dalam pemeringkatan respon sebuah mesin chatbot.

\section{REFERENSI}

Chaturvedi, A., Pandit, O., \& Garain, U. (2018). CNN for Text-Based Multiple Choice Question Answering. Proceedings of the 56th Annual Meeting of the Association for Computational Linguistics (Volume 2: Short Papers), 2, 272-277. Retrieved from https://aclanthology.coli.unisaarland.de/papers/P18-2044/p18-2044

Liu, B., Xu, Z., Sun, C., Wang, B., Wang, X., Wong, D. F., ... Zhang, M. (2018). Content-Oriented User Modeling for Personalized Response Ranking in Chatbots. 26(1), 122-133.

Wu, B., Wang, B., \& Xue, H. (2016). Ranking Responses Oriented to Conversational Relevance in Chat-bots. Proceedings of COLING 2016, the 26th International Conference on Computational Linguistics: Technical Papers, 652-662. Retrieved from https://www.aclweb.org/anthology/C/C1 6/C16-1063.pdf

Wu, Y., Wu, W., Xing, C., Zhou, M., \& Li, Z. (2016). Sequential Matching Network: A New Architecture for Multi-turn Response Selection in Retrieval-based 
Chatbots. Retrieved from http://arxiv.org/abs/1612.01627

Yu, J., Qiu, M., Jiang, J., Huang, J., Song, S., Chu, W., \& Chen, H. (2017). Modelling Domain Relationships for Transfer Learning on Retrieval-based Question Answering Systems in Ecommerce. 682-690. Retrieved from http://arxiv.org/abs/1711.08726 